\title{
Penggunaan Media Pembelajaran Interaktif Berbasis Audio-Visual Dengan Aplikasi Powtoon Untuk Meningkatkan Minat dan Hasil Belajar Siswa Fisika Di SMK Negeri 6 Samarinda
}

\author{
Ravena Hardyanti.T ${ }^{\mathrm{a},}$, Lambang Subagiyo ${ }^{\mathrm{b},}$, Riskan Qadar $^{\mathrm{c}, *}$ \\ 1,2,3 Fakultas Keguruan dan Ilmu Pendidikan - Universitas Mulawarman, Jl. Kuaro, Gn.Kelua, Samarinda, 75119 \\ *riskanqadar@fkip.unmul.ac.id
}

\begin{abstract}
ABSTRAK
Media pembelajaran interaktif berbasis audio-visual dengan aplikasi powtoon efektif digunakan untuk menarik minat belajar sehingga dapat meningkatkan hasil belajar siswa. Penelitian ini bertujuan untuk mengetahui minat dan hasil belajar siswa setelah diterapkannya media pembelajaran interaktif berbantuan audio-visual dengan aplikasi powtoon. Penelitian ini menggunakan pendekatan kuantitatif dengan desain one group pretest-posttest. Pengambilan data pada penelitian ini menggunakan angket, wawancara, dan tes tertulis. Data kuantitatif penelitian ini dianalisis menggunakan uji $N$-gain. Hasil analisis angket minat belajar siswa menunjukkan bahwa siswa memiliki minat yang tinggi terhadap pembelajaran dengan persentase rata-rata sebesar $83 \%$. Minat siswa pada kategori sangat tinggi sebesar 35\%, kategori tinggi sebesar $60 \%$, dan kategori sedang sebesar 5\%. Hasil wawancara menunjukkan bahwa siswa tertarik dan bersemangat terhadap proses pembelajaran. Analisis hasil belajar siswa menunjukkan bahwa kelas X TAB memperoleh N-gain sebesar 0.66 yang termasuk kategori sedang dengan nilai rata-rata sebesar 76,90.
\end{abstract}

Kata kunci : Media Pembelajaran Interaktif, Minat Belajar, Dan Hasil Belajar.

\section{ABSTRACT}

Interactive audio-visual media with powtoon application is used to attract learning interest so as to improve student learning outcomes. This study aims to find out the interests and learning outcomes of students after the implementation of interactive learning media. This research method is quantitative research with one group pretest-posttest design. The quantitative data of this research is analyzed by $N$-gain test. Data collection in this study using questionnaires, interviews, and written tests. The results of the analysis of student learning interest questionnaires showed that students have a high interest in learning with an average percentage of $83 \%$. Student interest in the category is very high at 35\%, the high category is 60\%, and the medium category is 5\%. The results of the interview showed that students were interested and passionate about the learning process. Analysis of student learning results showed that grade X TAB gained an N-gain of 0.66 which belonged to a moderate category with an average score of 76.90.

Keywords: Interactive Learning Media, Learning Interests, and Learning Outcomes

\section{PENDAHULUAN}

Perkembangan teknologi menyebabkan sebagian pelajar tidak tertarik lagi belajar namun malah terjerumus pada aktuvitas negatif yang berkembang sedang berkembang seperti tren game dan sosial media. Tren ini justru menjadikan siswa semakin jauh dari tugasnya sebagai seorang pelajar (Sudibyo,2011). Hal ini menjadi bukti tidak seimbangnya perkembangan dalam bidang pendidikan dan perkembangan tren dikalangan pelajar. Untuk itu diperlukan adanya pengembangan dalam pembelajaran agar dapat menarik kembali minat belajar siswa. Minat sangat berpengaruh terhadap prestasi hasil belajar siswa. siswa yang berminat terhadap suatu mata pelajaran akan bersungguhsungguh dalam mengikuti kegiatan pembelajaran, merasa senang saat mengikuti pelajaran, dan juga siswa akan cenderung mudah memahami mata pelajaran yang diajarkan jika kegiatan pembelajaran yang berlangsung mampu menarik minatnya (Fajar \& Riyana, 2017).

Minat (interest) adalah suatu rasa lebih suka dan rasa ketertarikan pada suatu hal atau aktivitas tanpa ada yang menyuruh (Slameto 2010). Minat merupakan faktor instrinsik yang dapat berpengaruh terhadap hasil belajar seseorang. Minat merupakan faktor penting penentu keberhasilan pembelajaran dan peningkatan prestasi peserta didik. Keberhasilan pembelajaran pada ranah kognitif dan psikomotorik dipengaruhi oleh kondisi afektif peserta didik yang memiliki minat belajar dan sikap 
positif terhadap pelajaran akan merasa senang mempelajari mata pelajaran tertentu, sehingga dapat mencapai hasil pembelajaran yang optimal.

Hasil belajar adalah kemampuan-kemampuan yang dimiliki siswa setelah menerima pengalaman belajar (Nana Sudjana, 2014). Hasil belajar biasanya digunakan sebagai patokan untuk mengetahui seberapa jauh sesorang menguasai materi yang sudah diajarkan karena, hasil belajar merupakan salah satu tujuan dari pendidikan yang ingin dicapai dalam proses pembelajaran. Dengan demikian dapat dikatakan bahwa pembelajaran berhasil apabila hasil belajar peserta didik juga berhasil.

Keberhasilan hasil belajar siswa dapat dicapai melalui pengembangan dalam kegiatan pembelajaran yang disesuaikan dengan teknologi yang berkembang saat ini seperti penggunaan media pembelajaran interaktif berbasis audio-visual sebagai penunjang proses pembelajaran yang dapat menarik minat belajar siswa. Media pembelajaran interaktif berbasis audio-visual sangat efektif dalam meningkatkan kompetensi siswa ditinjau dari peningkatan hasil belajar dan penguasaan konsep siswa (Usmeldi, 2015). Media interaktif berbasis audio-visual ini memiliki suatu dimensi baru terhadap pembelajaran karena dapat menyajikan gambar bergerak dengan suara yang menyertainya. Gambar bergerak atau animasi visual dan suara (audio) yang disertakan dalam animasi visual merupakan bagian dari indera penglihatan dan indera pendengaran. Kedua indera tersebut sangat berguna untuk memusatkan perhatian siswa selama kegiatan pembelajaran sehingga daya serap serta daya ingat siswa pada materi pembelajaran yang dikemas dalam bentuk media audio-visual dapat meningkat secara signifikan (Utami \& Julianto, 2013).

Penggunaan media dalam pembelajaran merupakan sarana penunjang yang dapat meningkatkan efisiensi dan efektivitas keberhasilan pembelajaran (Sutrisno \& Siswanto, 2016). Penggunaan teknologi dan media yang disesuaikan dan dirancang secara khusus bisa memberi kontribusi bagi pengajaran yang efektif dari seluruh siswa dan bisa membantu mereka meraih potensi tertingginya. Salah satu ciri atau karakteristik media pembelajaran interaktif adalah aspek kejelasan pesan agar menumbuhkan motivasi, tampilan desain yang menarik, dan memunculkan produk yang interaktif (Tarigan \& Siagian, 2015).

Salah satu aplikasi yang dapat digunakan dalam pembuatan media pembelajaran interaktif adalah powtoon. Powtoon merupakan aplikasi paling ideal bagi para guru untuk menunjang proses pembelajaran agar lebih menarik dan menyenangkan. Powtoon adalah suatu perangkat lunak pengolah media presentasi animasi berbasis Saas (Software as a Service) yang dapat diakses secara online melalui situs www.powtoon.com yang dapat digunakan sebagai alat bantu presentasi bagi guru dalam melaksanakan proses pembelajaran di dalam kelas (Yulia \& Novia, 2018). Penggunaan aplikasi powtoon cukup mudah karena menyediakan berbagai fitur, latar, animasi, gambar-gambar lucu dan menarik sesuai kebutuhan. Untuk itu media pembelajaran interaktif menggunakan powtoon pada pelajaran fisika dapat menciptakan suasana belajar yang menarik dan dapat meningkatkan minat belajar siswa sehingga dapat meningkatkan hasil belajar siswa. Selain itu media pembelajaran interaktif ini dapat diakses kapan saja oleh siswa sehingga tidak hanya bisa dipelajari dikelas saja. Hal ini tentu saja sangat memudahkan bagi siswa dalam mempelajari dan memahami materi karena bisa diakses berulang kali sebagai pembelajaran diluar kelas seperti dirumah.

Hasil penelitian ini dapat digunakan sebagai bahan pertimbangan bagi penelitian mendatang khususnya dalam bidang pendidikan yaitu sebagai acuan strategi pembelajaran yang mampu meningkatkan minat belajar peserta didik. Selain itu dapat juga dijadikan referensi untuk mengkaji perubahan sistem pembelajaran fisika yang disesuaikan dengan teknologi yang semakin berkembang agar dapat membawa kemajuan pada sistem pendidikan yang selama ini berjalan. Kemudian, diharapkan dengan menerapkan pembelajaran yang menyenangkan menggunakan media interaktif secara tidak sadar siswa memusatkan perhatiannya dalam belajar sehingga selain dapat menarik minat belajar siswa juga diperoleh pengetahuan dan pemahaman terhadap materi yang diajarkan. 


\section{METODE}

Metode penelitian yang digunakan adalah kuantitatif dengan desain one group pretest-posttest dimana tes ini dilakukan untuk membandingkan keadaan sebelum diberi perlakuan dan sesudah diberi perlakuan. Pretest dilakukan sebelum diberi perlakuan sementara posttest dilakukan setelah diberi perlakuan sebanyak 4 kali pertemuan. Dengan demikian hasil perlakuan dapat diketahui lebih akurat, karena dapat membandingkan keadaan sebelum dan sesudah diberi perlakuan.

Penelitian ini berlokasi di SMK Negeri 6 pada kelas X TAB semester ganjil tahun ajaran 2020/2021 Samarinda. Teknik pengumpulan data dilakukan dengan cara pengisian angket, wawancara, dan tes tertulis. Pernyataan angket pada penelitian ini difokuskan pada kisi-kisi aspek dan indikator minat belajar siswa menurut Slameto (2010). Berikut tabel kisi-kisi minat belajar siswa.

Tabel 1. Kisi-kisi Minat Belajar Fisika Siswa

\begin{tabular}{|c|c|c|c|c|c|}
\hline \multirow{2}{*}{ No } & \multirow{2}{*}{ Aspek Minat } & \multirow{2}{*}{ Indikator } & \multicolumn{2}{|c|}{ Nomor Item } & \multirow{2}{*}{ Jumlah } \\
\hline & & & Favorable & Unfavorable & \\
\hline \multirow[t]{2}{*}{1.} & \multirow{2}{*}{ Kognitif } & Perhatian dalam belajar & 1,3 & 2,4 & 4 \\
\hline & & Keterlibatan Peserta didik & 5,7 & 6,8 & 4 \\
\hline \multirow{3}{*}{2.} & \multirow{3}{*}{ Afektif } & Perasaan senang & $9,11,13$ & $10,12,14$ & 6 \\
\hline & & Rasa ingin tahu & $15,17,19$ & $16,18,20$ & 6 \\
\hline & & $\begin{array}{l}\text { Bahan pembelajaran dan } \\
\text { sikap guru }\end{array}$ & 21,23 & 22 & 3 \\
\hline 3. & Psikomotorik & Manfaat mata pelajaran & 25 & 24,26 & 3 \\
\hline \multicolumn{5}{|c|}{ Jumlah } & 26 \\
\hline
\end{tabular}

Wawancara yang dilakukan pada penelitian ini bertujuan untuk menguatkan hasil analisis angket minat belajar siswa. Wawancara dilakukan diakhir pertemuan setelah pengisian angket minat belajar siswa. Subjek wawancara dipilih berdasarkan kategori skor angket yang berbeda-beda. Dengan demikian, minat belajar siswa dapat diketahui lebih akurat karena dapat membandingkan minat belajar siswa dengan kategori yang berbeda-beda. Teknik analisis data minat belajar siswa pada penelitian ini menggunakan rumus persentase sebagai berikut:

$$
P=\frac{F}{N} \times 100 \%
$$

(Anas Sudijono, 2011)

Keterangan :

$\mathrm{P}=$ Angka persentase minat belajar siswa

$\mathrm{F}=$ Skor perolehan

$\mathrm{N}=$ Jumlah skor maksimum

Sedangkan teknik pengumpulan data untuk hasil belajar siswa menggunakan tes tertulis berupa soal uraian (essay) yang berjumlah 10 butir soal dengan ranah kognitif C2 sebanyak 2 soal, C3 sebanyak 6 soal, dan C4 sebanyak 2 soal. Dalam penelitian ini tes digunakan untuk mengukur hasil belajar yang dicapai siswa. Teknik analisis data hasil belajar siswa pada penelitian ini menggunakan uji $N$-gain dengan rumus sebagai berikut:

$$
N-\text { Gain }=\frac{\text { nilai posttest-nilai pretest }}{\text { nilai maksimum-nilai pretest }} .
$$




\section{HASIL DAN PEMBAHASAN}

\section{Minat Belajar Siswa}

Hasil pengisian angket minat belajar siswa kelas $\mathrm{X}$ TAB terhadap penggunaan media pembelajaran interaktif berbasis audio-visual dengan aplikasi powtoon disajikan dalam grafik berikut.

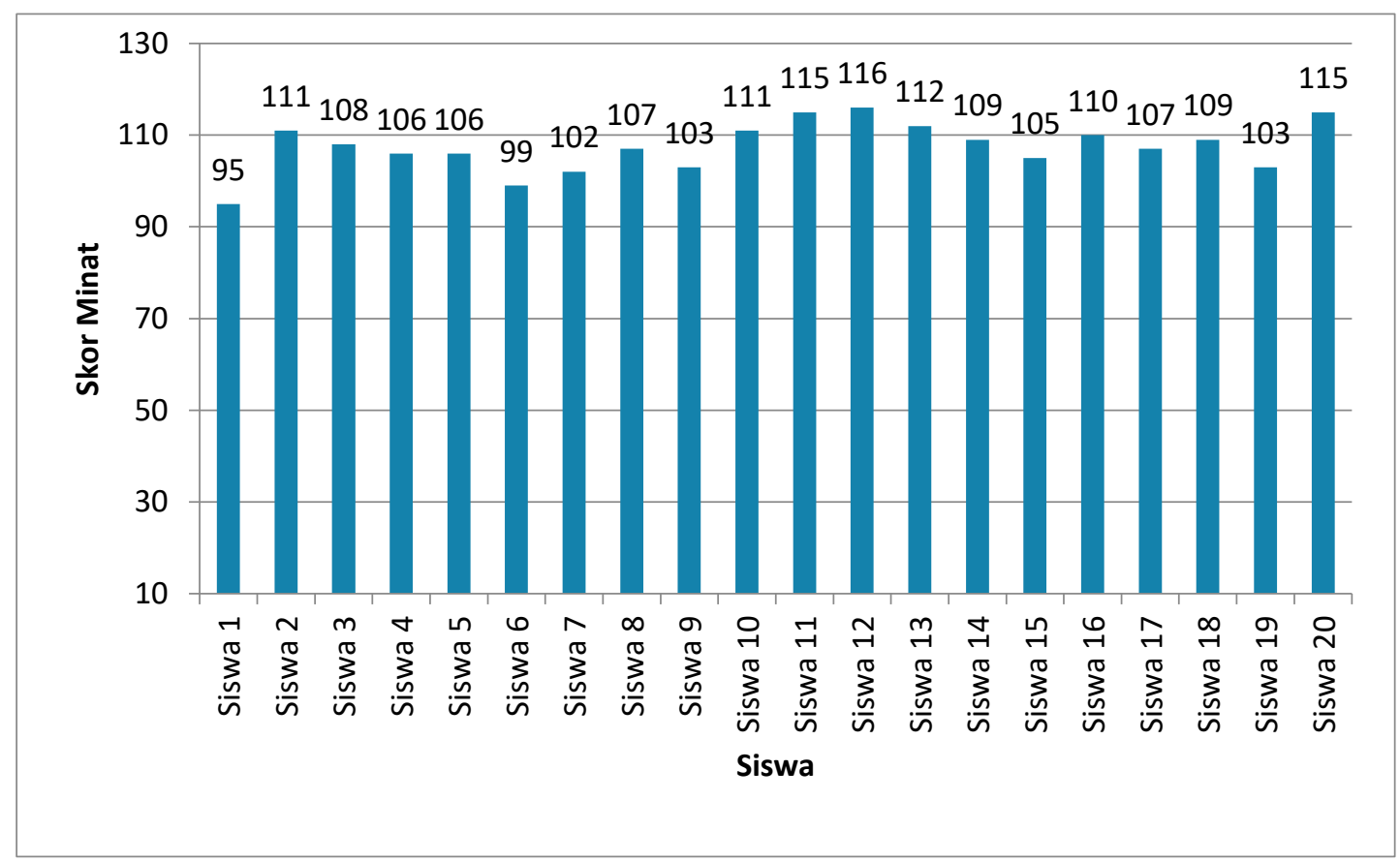

Gambar 1. Grafik skor minat belajar siswa kelas X TAB

Berdasarkan gambar 1, pengisian angket minat belajar siswa memperoleh skor dari rentang 95 hingga 116. Siswa yang memberikan skor 95 dengan kriteria sedang disebabkan oleh minimnya partisipasi siswa dalam proses pembelajaran. Siswa ini seringkali terlambat serta kurang fokus mengikuti pembelajaran yang berlangsung. Hal ini dikarenakan siswa tersebut mengikuti pembelajaran daring sekaligus bekerja. Berdasarkan pengamatan selama pembelajaran siswa yang memberikan skor tinggi pada angket memiliki antuasias yang tinggi terhadap pembelajaran yang diberikan. Siswa tersebut sangat aktif dalam menanggapi permasalahan yang disajikan serta memiliki rasa ingin tahu yang tinggi dibuktikan dengan keaktifan siswa dalam kegiatan tanya-jawab. Adanya perbedaan yang cukup besar terhadap pengisan angket disebabkan oleh perbedaan sikap siswa selama proses pembelajaran. Perolehan skor angket minat belajar siswa kemudian dianalisis sehingga memperoleh persentase dengan masing-masing kategori yang dapat dilihat pada tabel berikut.

Tabel 2. Persentase skor minat belajar siswa

\begin{tabular}{cccc}
\hline Persentase Skor Minat (\%) & Kriteria & Frekuensi & Persentase Siswa (\%) \\
\hline $85-100$ & Sangat Tinggi & 7 & 35 \\
$75-84$ & Tinggi & 12 & 60 \\
$60-74$ & Sedang & 1 & 5 \\
$40-59$ & Rendah & 0 & 0 \\
$0-39$ & Sangat Rendah & 0 & 0 \\
\hline
\end{tabular}

Hasil analisis angket minat belajar siswa terhadap penggunaan media pembelajaran interaktif berbasis audio-visual dengan aplikasi powtoon menunjukkan bahwa siswa memberikan respon yang 
baik. Persentase minat belajar siswa berada pada kategori sedang hingga sangat tinggi. Hal ini menunjukkan bahwa sebagian besar siswa memiliki minat yang tinggi terhadap penggunaan media pembelajaran interaktif berbasis audio-visual dengan aplikasi powtoon dengan persentase rata-rata sebesar $83 \%$. Dengan adanya media pembelajaran interaktif yang diterapkan dapat mengatasi kesulitan siswa dalam memahami materi ajar, selain itu media yang disediakan dapat diakses oleh siswa diluar jam pembelajaran fisika. Sehingga siswa yang masih kurang memahami materi yang disampaikan dapat mengulang secara mandiri materi yang telah disampaikan melalui link media pembelajaran interaktif yang diberikan.

Minat siswa terhadap penggunaan media pembelajaran interaktif berbasis audio-visual dengan aplikasi powtoon dibagi berdasarkan 3 aspek yaitu: (1) Kognitif yang terdiri dari perhatian dalam belajar dan keterlibatan peserta didik, (2) Afektif yang terdiri dari perasaan senang, rasa ingin tahu, bahan pembelajaran dan sikap guru, (3) Psikomotorik yang terdiri dari manfaat mata pelajaran. Hasil analisis angket minat belajar siswa untuk setiap aspek dan indikator dapat dilihat pada gambar berikut.

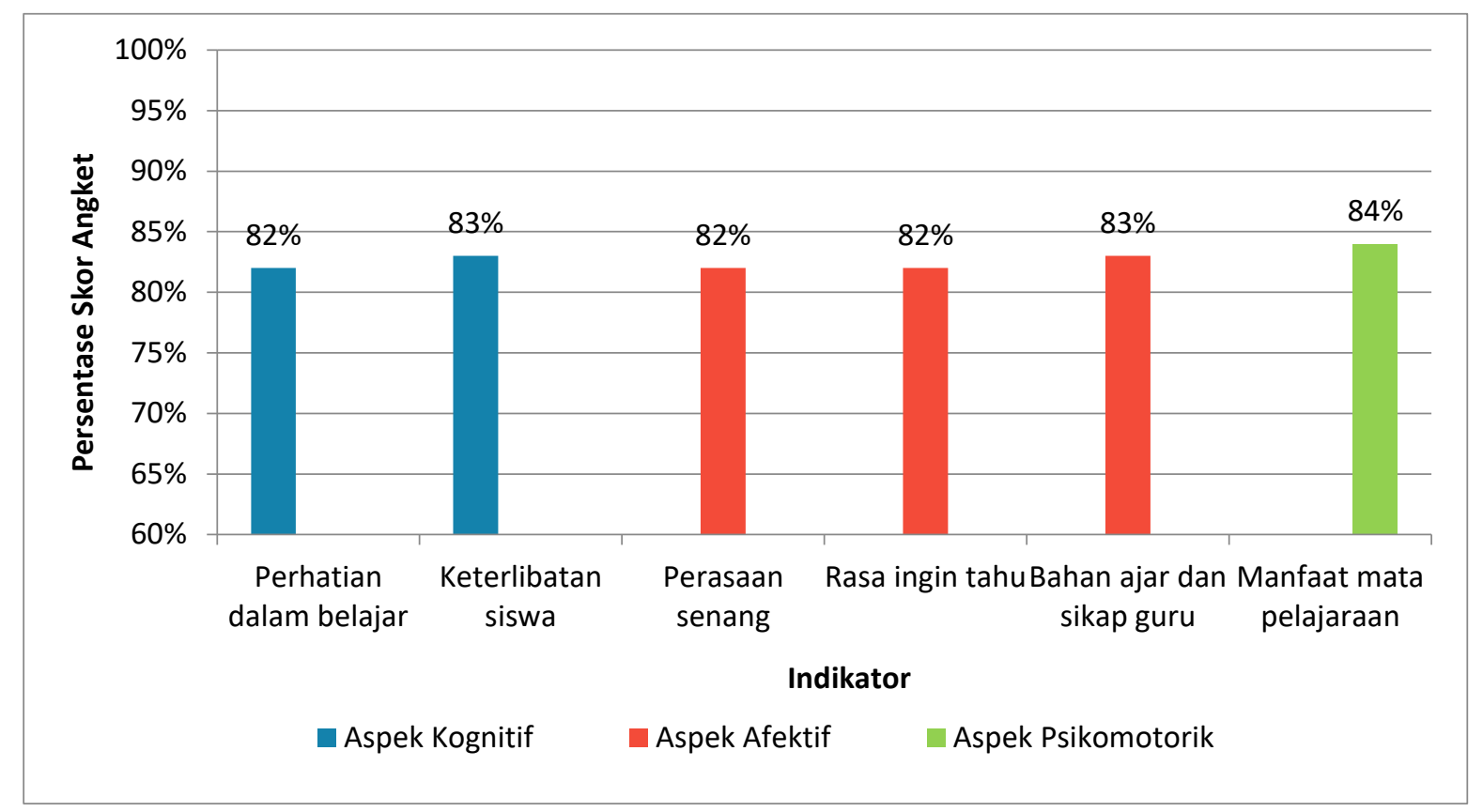

Gambar 3. Persentase minat belajar siswa tiap aspek dan indikator

Gambar 3 menunjukkan hasil analisis angket berupa persentase minat belajar siswa pada setiap aspek dan indaktor. Untuk aspek kognitif pada indikator perhatian dalam belajar dan keterlibatan peserta didik hasil analisis menunjukkan bahwa kedua indikator tersebut memperoleh rata-rata kategori yang tinggi dengan persentase masing-masing sebesar $82 \%$ dan $83 \%$. Hal ini membuktikan bahwa selama pembelajaran, media interaktif berfungsi dengan baik untuk dapat memusatkan perhatian siswa dan membuat siswa tertarik untuk terlibat dalam pembelajaran seperti memberikan tanggapan dan mencetuskan gagasan terkait materi pembelajaran. Hal ini sejalan dengan penelitian yang dilakukan oleh Devi et al., (2018) yang menemukan bahwa media interaktif memperoleh respon positif pada aspek kognitif dengan persentase rata-rata sebesar $79 \%$ yang termasuk dalam kategori tinggi.

Untuk aspek afektif pada indikator perasaan senang, rasa ingin tahu, dan bahan pembelajaran serta sikap guru. Hasil analisis menunjukkan bahwa ketiga indikator tersebut termasuk dalam kategori tinggi dengan persentase masing-masing indikator sebesar $82 \%, 82 \%$, dan $83 \%$. Hal ini membuktikan bahwa pembelajaran menggunakan media interaktif dapat menarik minat siswa dengan menimbulkan 
perasaan senang dan tidak mudah bosan, kemudian dapat merangsang rasa ingin tahu siswa terhadap materi pembelajaran yang disajikan. Hal ini sejalan dengan penelitian yang dilakukan oleh Wulandari (2020) yang menyatakan bahwa media pembelajaran interaktif termasuk dalam kategori tinggi ditinjau dari semangat belajar siswa di dalam kelas serta keaktifan siswa terhadap pembelajaran yang digunakan.

Untuk aspek psikomotorik pada indikator manfaat mata pelajaran, hasil analisis menunjukkan bahwa indikator tersebut memperoleh kategori yang tinggi dengan persentase sebesar $84 \%$. Hal ini membuktikan bahwa media interaktif mampu menarik minat siswa melalui manfaat mata pelajaran. Selama proses pembelajaran berlangsung hampir seluruh siswa dapat menjawab manfaat dari materi yang disampaikan, serta mampu mengaitkan manfaat pembelajaran dengan aplikasi dalam kehidupan sehari-hari. Hal ini telah membuktikan bahwa adanya media interaktif selama pembelajaran dapat meningkatkan minat belajar siswa pada seluruh aspek dan indikator. Hal ini sejalan dengan penelitian Ayu (2014) yang menunjukkan bahwa minat siswa terhadap pembelajaran menggunakan media audio-visual memperoleh respon positif oleh siswa yang mengharapkan bahwa pembelajaran dapat diterapkan untuk semua materi fisika.

Meningkatnya minat belajar siswa ini juga diperkuat dengan hasil wawancara yang dilakukan dengan mengambil 3 subjek dengan syarat tertentu yaitu: siswa dengan persentase minat kategori sedang, siswa dengan persentase minat kategori tinggi, dan persentase minat kategori sangat tinggi. Berdasarkan hasil wawancara, minat belajar siswa terhadap pembelajaran berada pada rata-rata kategori yang tinggi, hal ini didasarkan pada hasil wawancara yaitu siswa berharap media interaktif dapat digunakan untuk semua materi fisika, selain menimbulkan perasaan senang siswa juga merasa tertarik karena media interaktif menampilkan visualisasi penerapan materi dalam kehidupan seharihari sehingga membuat siswa mampu mengaitkannya dengan penerapan lain. Siswa juga lebih mudah mengerti dan tidak mudah bosan serta bersemangat selama proses pembelajaran.

Hasil wawancara juga menunjukkan bahwa masih terdapat beberapa kekurangan yaitu jaringan internet yang kurang stabil sehingga membuat siswa merasa bahwa pembelajaran daring yang dilakukan masih kurang efektif. Peneliti menduga bahwa penggunaan media pembelajaran interaktif yang diterapkan akan lebih baik lagi jika digunakan dengan pembelajaran tatap muka. Hal ini didasarkan pada penelitian yang dilakukan oleh Ariyanto \& Kantun (2018) yang menyatakan bahwa penelitian yang dilakukan secara tatap muka sehingga lebih efektif dibandingkan pembelajaran yang dilakukan secara daring. Penelilitian ini pun menunjukkan peningkatan minat belajar terhadap penggunaan media pembelajaran interaktif dengan persentase rata-rata sebesar $85 \%$.

Berdasarkan penelitian yang telah dilakukan dapat disimpulkan bahwa penggunaan media pembelajaran interaktif berbasis audio-visual dengan aplikasi powtoon dapat meningkatkan minat belajar siswa khususnya pada materi impuls dan momentum. Penggunaan media interaktif selama pembelajaran secara efektif dapat meningkatkan minat belajar siswa terhadap kegiatan belajarmengajar. Hal ini sejalan dengan penelitian yang dilakukan oleh Ariyanto \& Kantun (2018) yang menunjukkan bahwa terdapat peningkatan minat belajar siswa terhadap penggunaan media powtoon.

\section{Hasil Belajar Siswa}

Hasil belajar siswa diketahui melalui pretest yang diberikan diawal pertemuan dan posttest yang diberikan diakhir pertemuan. Jika disajikan dalam bentuk grafik masing-masing perolehan nilai pretest dan posttest siswa dapat dilihat pada gambar berikut. 


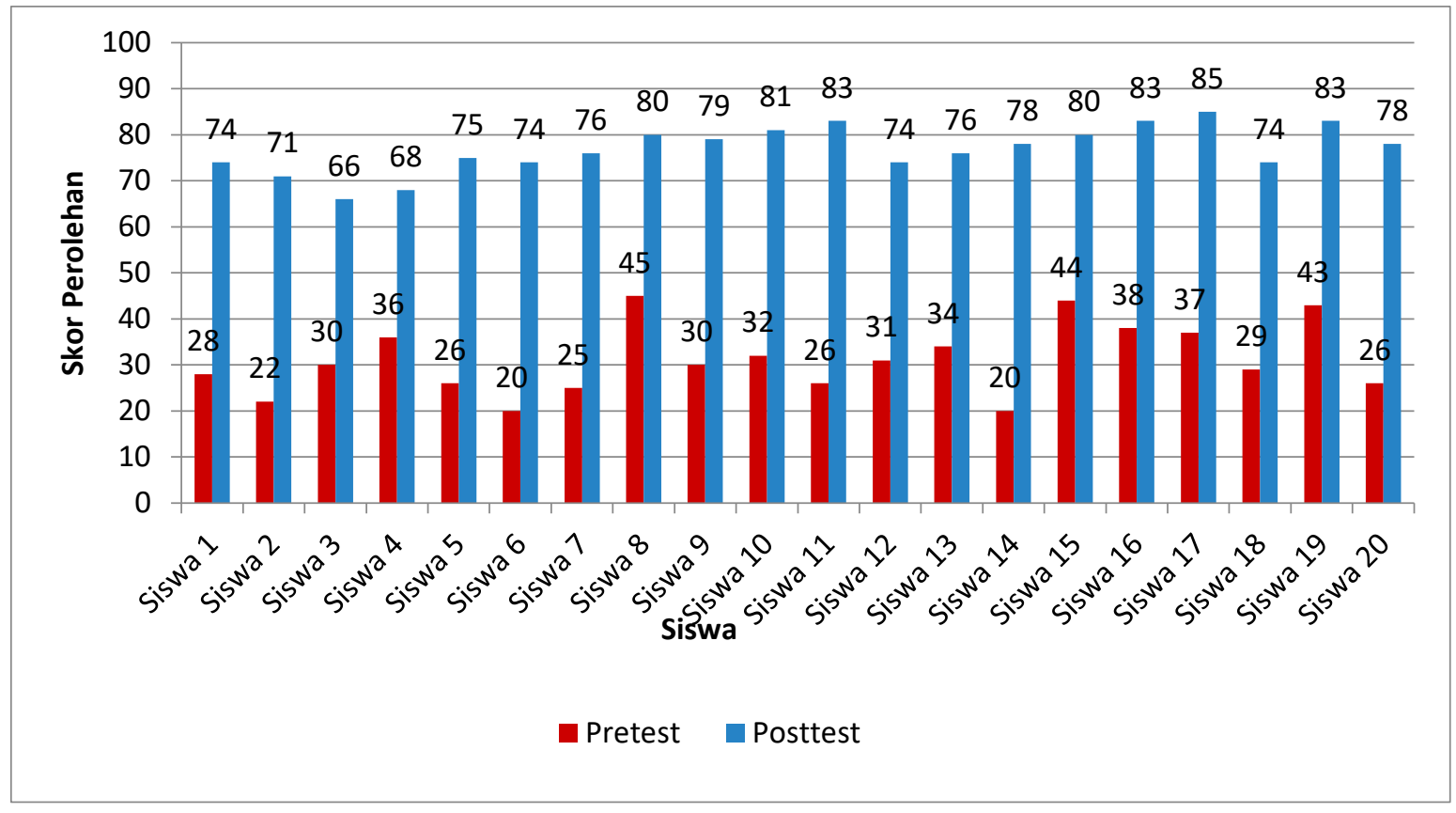

Gambar 4. Grafik hasil pretest dan posttest kelas X TAB

Berdasarkan gambar 4 hasil analisis pretest dan posttest menunjukkan bahwa siswa memperoleh nilai pretest dari rentang 20 hingga 45 sedangkan hasil analisis nilai posttest siswa memperoleh nilai dari rentang 66 hingga 85 . Kemudian, Jika disajikan dalam bentuk tabel hasil analisis menunjukkan bahwa terdapat peningkatan hasil belajar siswa ditinjau berdasarkan nilai pretest dan posttest siswa.

Tabel 3. Hasil Rata-rata Pretest dan Posttest

\begin{tabular}{cccccc}
\hline \multicolumn{5}{c}{ Descriptive Statistics } \\
\hline & $\mathrm{N}$ & Minimum & Maximum & Mean & Std.Deviation \\
\hline Pretest & 20 & 20.00 & 45.00 & 31.10 & 7.53 \\
\hline Posttest & 20 & 66.00 & 85.00 & 76.90 & 5.08 \\
\hline
\end{tabular}

Berdasarkan hasil rata-rata pretest dan posttest dapat dilihat bawa hasil pretest pada kelas $\mathrm{X}$ Teknik Alat Berat (TAB) menunjukkan rerata sebesar 31,10 dengan nilai maksimum 45,00. Setelah diberi perlakuan berupa penggunaan media pembelajaran interaktif berbasis audio-visual dengan aplikasi powtoon hasil posttest siswa kelas X TAB mengalami peningkatan dengan rerata 76.90 dan nilai maksimum sebesar 85,00.

Kemudian, hasil analisis menggunakan uji- $N$-gain menunjukan bahwa hasil belajar siswa memiliki nilai $\mathrm{N}$-gain sebesar 0,66 yang termasuk dalam kategori sedang. Untuk persentase skor $\mathrm{N}$ gain siswa dapat dilihat pada tabel berikut.

Tabel 4. Kriteria $N$-gain Hasil Belajar Siswa

\begin{tabular}{cccc}
\hline Kriteria Perolehan $N$-Gain & Kriteria & Frekuensi & Presentase \\
\hline$N-$ Gain $\geq 0,7$ & Tinggi & 8 & $40 \%$ \\
$0,3<N-$ Gain $<0,7$ & Sedang & 12 & $60 \%$ \\
$N-$ Gain $\leq 0,3$ & Rendah & 0 & $0 \%$ \\
\hline
\end{tabular}

Pada tabel 4 dapat diketahui bahwa kriteria $N$-gain peserta didik kelas X TAB cenderung berada pada kriteria sedang dan tinggi. Untuk memperjelas data klasifikasi $N$-gain di atas, Maka dapat disajikan dalam bentuk grafik seperti pada gambar 5. 


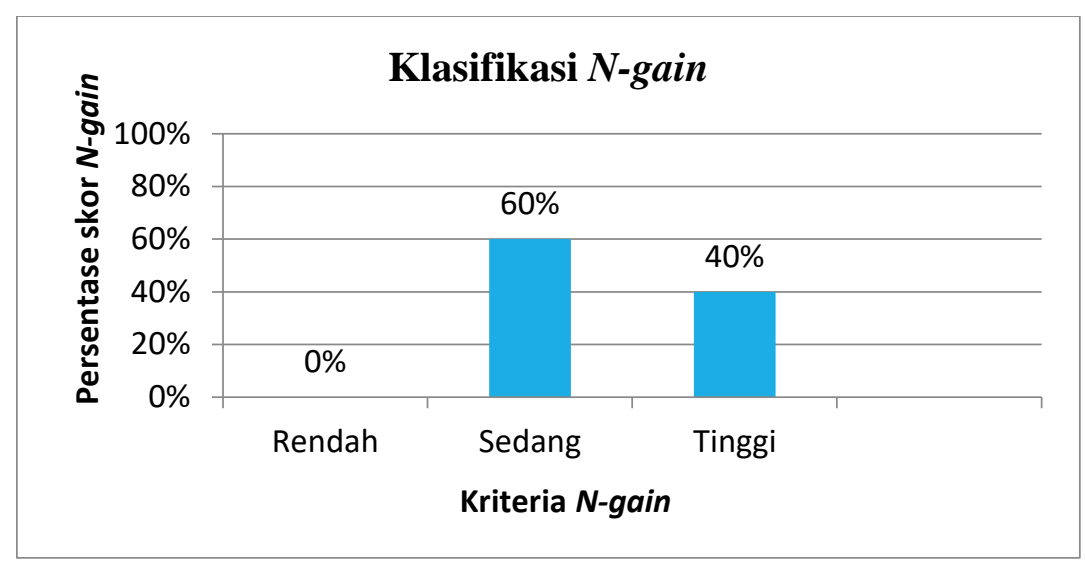

Gambar 5. Grafik klasifikasi $n$-gain siswa kelas X TAB

Gambar 5 menunjukkan bahwa terdapat $40 \%$ siswa yang memiliki nilai $N$-gain terkategori tinggi dan $60 \%$ siswa memiliki nilai $N$-gain terkategori sedang. Hal ini menunjukkan bahwa pembelajaran yang dilakukan sudah cukup baik dengan $N$-gain yang cenderung pada kategori sedang hingga tinggi. Sebanyak $40 \%$ siswa dengan nilai $\mathrm{N}$-gain terkategori tinggi menunjukkan bahwa penggunaan media pembelajaran interaktif berbasis audio-visual dengan aplikasi powtoon dapat meningkatkan hasil belajar secara signifikan. Hal ini dapat menjadi motivasi untuk penelitian berikutnya bahwasanya penggunaan media pembelajaran interaktif berbasis audio-visual dengan aplikasi powtoon akan lebih optimal jika pembelajaran dilakukan dengan tatap muka. Dengan pembelajaran tatap muka, guru secara langsung dapat mengawasi jalannya proses pembelajaran. Berbeda halnya dengan pembelajaran daring, dimana guru masih kesulitan untuk mengawasi kegiatan belajar mengajar dan memastikan siswa memahami materi yang disampaikan. Sehingga media pembelajar interaktif ini dapat berfungsi dengan baik sebagai sarana yang dapat memusatkan perhatian siswa, membangkitkan motivasi, serta dapat mengaktifkan suasana belajar sehingga dapat meningkatkan hasil belajar siswa. Hal ini sejalan dengan penelitian yang dilakukan oleh Radityan et al., (2016) yang menunjukkan terdapat peningkatan hasil belajar siswa dengan perolehan $N$-gain sebesar 0,67 yang termasuk dalam kategori sedang. Hal ini membuktikan bahwa penggunaan media pembelajaran interaktif dapat meningkatkan hasil belajar siswa. Tingginya minat siswa terhadap pembelajaran sejalan dengan meningkatnya hasil belajar siswa, hal ini sejalan dengan penelitian yang dilakukan oleh Nadun (2017) yang menunjukkan adanya pengaruh minat terhadap hasil belajar siswa.

Peningkatan minat belajar siswa terhadap pembelajaran memiliki keterkaitan yang erat terhadap hasil belajar siswa. Hal ini telah dibuktikan melalui penelitian yang dilakukan dengan penggunaan media interaktif berbasis audio-visual dimana siswa yang memberikan skor dengan kriteria sedang hingga tinggi pada pengisian angket, memperoleh rata-rata hasil belajar dengan $\mathrm{N}$-gain yang terkategori sedang. Sedangkan siswa yang memberikan skor pengisian angket dengan kriteria tinggi hingga sangat tinggi, memperoleh rata-rata hasil belajar dengan $\mathrm{N}$-gain yang terkategori tinggi. Hal ini sejalan dengan penelitian yang dilakukan oleh Sari et al., (2016) yang menunjukkan bahwa minat belajar siswa terhadap kegiatan pembelajaran yang berlangsung berpengaruh secara signifikan terhadap hasil belajar siswa. Sebagai contoh siswa yang berminat terhadap kegiatan pembelajaran menggunakan media audio-visual pada mata pelajaran tertentu, secara tidak sadar akan memusatkan perhatiannya selama kegiatan pembelajaran, siswa juga akan rajin dan bersungguh-sungguh karena merasa senang mengikuti kegiatan pembelajaran, bahkan siswa mampu memecahkan masalahmasalah yang disajikan dengan mudah, serta siswa akan mudah memahami pelajaran. Dengan demikian, penelitian ini menunjukkan bahwa seiring dengan tingginya minat belajar siswa terhadap proses pembelajaran maka dapat meningkat pula pencapaian hasil belajar siswa. 


\section{SIMPULAN}

Penelitian ini menunjukkan bahwa penggunaan media pembelajaran interaktif berbasis audiovisual dengan aplikasi powtoon dapat meningkatkan minat dan hasil belajar siswa pada materi impuls dan momentum. Minat belajar siswa terhadap penggunaan media pembelajaran interaktif berbasis audio-visual dengan aplikasi powtoon memperoleh persentase rata-rata sebesar $83 \%$ yang termasuk ke dalam kategori tinggi serta hasil wawancara menunjukkan bahwa penggunaan media pembelajaran interaktif berbasis audio-visual dengan aplikasi powtoon dapat menarik perhatian siswa terhadap materi pembelajaran dan membuat siswa menjadi bersemangat. Untuk hasil belajar siswa terhadap penggunaan media pembelajaran interaktif berbasis audio-visual dengan aplikasi powtoon pada materi impuls dan momentum diperoleh $\mathrm{N}$-Gain sebesar 0,66 yang termasuk dalam kategori sedang dengan nilai rata-rata sebesar 76,90.

\section{REFERENSI}

Ariyanto, R., \& Kantun, S. (2018). Penggunaan Media Powtoon Untuk Meningkatkan Hasil Belajar Siswa Pada Kompetensi Dasar Mendeskripsikan Pelaku-Pelaku Ekonomi Dalam Sistem Perekonomian Indonesia (Studi Kasus Pada Siswa Kelas VIIID SMP Nurul Islam Jember Semester Genap Tahun Pelajaran 2017. 12, 122-127. https://doi.org/10.19184/jpe.v12i1.7622

Ayu, I. (2014). Pemanfaatan Media Audio Visual Sebagai Sumber Pembelajaran Sejarah. 3(1).

Devi, C., Utari, T. S. G., \& Nurkanti, M. (2018). Penggunaan Media Pembelajaran MIVI (Media Interaktif Visual) Untuk Meningkatkan Hasil Belajar Siswa Pada Topik Sistem Gerak Manusia. Jurnal Bioedukatika, 6(1), 1. https://doi.org/10.26555/bioedukatika.v6i1.7263

Fajar, S., \& Riyana, C. (2017). Pengaruh Penggunaan Media. 3(2), 101-114.

Nadun. (2017). Pengaruh Minat Belajar Siswa Terhadap Hasil Belajar Trigonometri. 2348, 67-76.

Nana Sudjana. 2014. Penilaian Proses Hasil Belajar Mengajar Cetakan Kedelapan belas. Bandung: PT. Remaja Rosdakarya.

Radityan, F. T., Kuntadi, I., \& Komaro, M. (2016). Pengaruh Multimedia Interaktif Terhadap Hasil Belajar Siswa Pada Kompetensi Perbaikan Differential. Journal of Mechanical Engineering Education, 1(2), 239. https://doi.org/10.17509/jmee.v1i2.3807

Sari, I. N., Saputri, D. F., \& Sasmita. (2016). Prestasi Belajar Fisika Pada Siswa Kelas XI IPA SMA Negeri 1 Galing Kabupaten Sambas. Jurnal Edukasi Matematika Dan Sains, 4(2), 108-114.

Slameto, 2010. Belajar dan Faktor-Faktor yang Mempengaruhinya. Jakarta: Rineka Cipta.

Sudibyo, L. (2011). Peranan dan Dampak Teknologi Informasi dalam Dunia Pendidikan di Indonesia. Widyatama, 20(2), 175-185.

http://download.portalgaruda.org/article.php?article=268282\&val=7107\&title=Peranan

Sutrisno, V. L. P., \& Siswanto, B. T. (2016). Faktor-Faktor Yang Mempengaruhi Hasil Belajar Siswa Pada Pembelajaran Praktik Kelistrikan Otomotif Smk Di Kota Yogyakarta. Jurnal Pendidikan Vokasi, 6(1), 111. https://doi.org/10.21831/jpv.v6i1.8118

Tarigan, D., \& Siagian, S. (2015). Pengembangan Media Pembelajaran Interaktif Pada Pembelajaran Ekonomi. Jurnal Teknologi Informasi \& Komunikasi Dalam Pendidikan, 2(2), 187-200. https://doi.org/10.24114/jtikp.v2i2.3295

Usmeldi. (2015). Efektivitas Penerapan Media Pembelajaran Interaktif dengan Software Autorun untuk Meningkatkan Kompetensi Fisika Siswa SMK Negeri 1 Padang.

Utami, K., \& Julianto. (2013). Penggunaan Media Audio Visual untuk Meningkatkan Pemahaman 
Konsep Siswa di Sekolah Dasar. Jurnal Penelitian Pendidikan Guru Sekolah Dasar, 1(2), 1-10.

Wulandari, S. (2020). Media Pembelajaran Interaktif Untuk Meningkatkan Minat Siswa Belajar Matematika Di SMP 1 Bukit Sundi. Indonesian Journal of Technology, Informatics and Science (IJTIS), 1(2), 43-48. https://doi.org/10.24176/ijtis.v1i2.4891 